\title{
Pemberian Probiotik Berbasis Mikroorganisme Lokal (MOL) Terhadap Kualitas Karkas Broiler
}

\section{Probiotic Giving Based on Local Microorganisms (MOL) Against the Quality of Broiler Carcasses}

\author{
Ujang Suryadi $^{1^{*}}$, Anang Febry Prasetyo ${ }^{1}$, Erna K $^{2}$, Septy EE $^{2}$, Fuad A $^{2}$, Galih FF $^{2}$ \\ ${ }^{1}$ Staf Pengajar Program Studi Manajemen Bisnis Unggas \\ Jurusan Peternakan Politeknik Negeri Jember \\ ${ }^{2}$ Mahasiswa Program Studi Manajemen Bisnis Unggas \\ Jurusan Peternakan Politeknik Negeri Jember \\ *email : usurpoltek@yahoo.co.id
}

\begin{abstract}
Abstrak
Probiotik berbasis Mikroorganisme Lokal (MOL) dari rumen sapi dan usus ayam telah dibuat dan diteliti dampaknya terhadap kualitas karkas boiler jika digunakan sebagai pengganti Antibioic Growth Promotor (AGP). Penelitian ini bertujuan untuk mempelajari pengaruh pemberian probiotik MOL terhadap kualitas karkas broiler. Penelitian dilakukan pada bulan Juli sampai Agustus 2018 terhadap 200 ekor broiler tanpa dibedakan jenis kelaminnya. Aplikasi probiotik dilakukan dengan mencampurnya pada ransum yang diberikan sejak umur 1 sampai 35 hari. Penelitian ini menggunakan metode eksperimental dengan menggunakan Rancangan Acak Lengkap pola searah dengan empat perlakuan yaitu; P0 (Pakan BR 1 tanpa probiotik), P $_{1}$ (Pakan BR $1+$ probiotik dengan dosis $5 \mathrm{ml} / \mathrm{Kg}$ ), $P_{2}$ (Pakan Pakan BR $1+$ probiotik dengan dosis $10 \mathrm{ml} / \mathbf{K g}$ ), $P_{3}($ Pakan Pakan BR 1 + probiotik dengan dosis $15 \mathrm{ml} / \mathrm{Kg}$ ), masing-masing perlakuan diulang 5 kali. Parameter yang diamati meliputi; persentase karkas, persentase lemak abdominal dan persentase lemak visceral. Hasil penelitian menunjukkan probiotik berbasis MOL mengandung bakteri Bifidobacterium 3,5 $\times 10^{7} \mathrm{CFU} / \mathrm{ml}$, Bacillus $0,9 \times 10^{6} \mathrm{CFU} / \mathrm{ml}$, Streptococcus $1,06 \times 10^{6} \mathrm{CFU} / \mathrm{ml}$, dan Lactobacillus $12,5 \times 10^{7} \mathrm{CFU} / \mathrm{ml}$, setelah diaplikasikan dalam penelitian menunjukkan bahwa penambahan probiotik MOL pada pakan BR 1 tidak berpengaruh nyata $(P>0.05)$ tehadap persentase karkas, lemak abdominal dan visceral broiler dibandingkan dengan persentase karkas, lemak abdominal dan visceral broiler tanpa diberi probiotik, demikian juga diantara pesentase karkas, lemak abdominal dan visceral broiler yang diberi probiotik pada level yang berbeda tidak menunjukkan persentase yang berbeda nyata $(\mathbf{P}>0.05)$, dengan demikian MOL dapat diberikan pada broiler karena presentase karkas yang diperoleh masih dalam kisaran normal yaitu 72,02-73,63\%, persentase lemak abdominal antara $1,54 \%$ $1,85 \%$, dan persentase lemak visceral $0,45 \%-0,68 \%$.
\end{abstract}

Keywords : Probiotik, AGP, Rumen, Usus ayam, daging

\section{PENDAHULUAN}

Performa produksi broiler yang baik ditentukan oleh mortalitas rendah, pertambahan bobot badan dan bobot akhir yang berat pada saat umur panen, efisien merubah ransum menjadi daging, bobot atau presentase karkas tinggi, dan kualitas daging yang baik pada saat ayam dipotong, semua karekateristik performa tersebut merupakan sifat unggul yang dimiliki oleh broiler. Pemeliharaan broiler sampai tahun 2017 dalam pakannya selalu ditambahkan AGP (Antibiotics Growth Promoters) untuk pemicu pertumbuhan, tetapi sejak 1 Januari 2018 Pemerintah Indonesia mengeluarkan UU No 18/2009 jucto No 41/2014 pasal 22 ayat 4c tentang pelarangan penggunaan pakan yang dicampur hormon tertentu dan atau antibiotik sebagai imbuhan pakan.

Pelarangan penggunaan AGP pada broiler mengakibatkan produktivitas broiler menurun. Berdasarkan informasi peternak ayam di Blitar terjadi penurunan bobot badan broiler sampai $40 \%$ dari bobot semula dan penurunan kapasitas produksi 
Ujang Suryadi, Anang Febry Prasetyo, Erna K, Septy EE, Fuad A, Galih FF. Pemberian Probiotik Berbasis Mikroorganisme Lokal (MOL) Terhadap Kualitas Karkas Broiler

telur dari 90\% menjadi 40\% (Riady, 2018). Pelarangan penggunaan AGP berdampak terhadap penuruan produksi, untuk menanggulangi itu maka peternak broiler banyak yang mengaplikasikan penggunaan probiotik sebagai pengganti AGP.

Probiotik sebagai pengganti AGP dapat dibuat dari monokultur atau konsorsium beberapa mikroorganisme probiotik. Mikrooorganisme yang biasa digunakan untuk probiotik dari golongan bakteri adalah strain Bifidobacterium, Enterococcus, Lactobacillus, Bacillus, Pediococcus dan Streptococcus, beberapa probiotik juga mengandung ragi dan jamur selain bakteri (Yirga, 2015). Bakteri Bifidobacterium, Enterococcus, Lactobacillus, Bacillus, Pediococcus dan Streptococcus, dapat ditemukan di bagian saluran pencernaan ternak, oleh karena dibuat probiotik dengan memanfaatkan konsorsium bakteri rumen ternak ruminansia atau usus halus dan seca unggas, atau campuran bakteri yang berasal dari keduanya, probiotik ini yang kemudian dikenal dengan probiotik berbasis MOL (Mikroorganisme Lokal).

Pemberian probitik pada broiler yang dilakukan oleh peternak menujukkan hasil yang beragam terhadap performa produksi broiler. Pemberian probiotik pada ternak dapat memberikan keseimbangan mikroflora di dalam saluran pencernaan. Probiotik dapat meningkatkan laju pertumbuhan, dengan manfaat probiotik nafsu makan meningkat dan menghasilkan vitamin serta enzim-enzim pencernaan (Abrar dan Raudhati, 2006), namun demikian perlu juga dikaji terhadap kualitas karkas dan daging broiler yang diberi probiotik.

Dewasa ini Kualitas karkas sudah menjadi bahan perhatian bagi komsumen daging ayam, mereka sudah memilih karkas yang perdagingannya lebih banyak dan memiliki kadar lemak abdominal yang rendah. Beberapa hasil penelitian penggunaan probiotik pada ransum yang diberikan pada ternak dapat menurunkan kadar lemak dan kolestrol. Santoso dkk.(1999) mengungkapkan bahwa suplementasi B. Subtilis dalam ransum broiler secara signifikan $(\mathrm{P} \quad<0,05)$ mengurangi penumpukan lemak karkas dan trigliserida dalam serum, hati dan karkas.

\section{MATERI DAN METODE}

Penelitian dilaksanakan di Politeknik Negeri Jember dengan menggunakan broiler strain CP 707 yang tidak dibedakan jenis kelaminnya sebanyak 250 ekor. Broiler dipeliharan mulai DOC sampai umur panen 35 hari. Pada masa brooding, broiler dipelihara di dalam 20 petak masang masing berukuran 52 × 38 × $37 \mathrm{~cm}$ dengan lantai litter yang diisi oleh 10 ekor DOC, setiap petak diberi lampu pijar 15 watt yang berfungsi sebagai pemanas dan penerang. Pada periode finisher, petak diperlebar ukurannya menjadi $1 \mathrm{~m}^{2}$ untuk 10 ekor. Penempatan broiler dalam petak dilakukan pengacakan. Peralatan yang digunakan dalam penelitian ini terdiri dari; 1. Timbangan O'haus kapasitas $1300 \mathrm{~g}$ dengan ketelitian 0,05 gram, digunakan untuk menimbang DOC. 2. Timbangan digital kapasitas $5 \mathrm{~kg}$ digunakan untuk menimbang pakan dan ayam mulai umur empat minggu. 3. Higrotermometer untuk mengukur suhu dan kelembaban dalam kandang. 4. Tempat pakan dan minum 5. Plastik untuk menyimpan sampel pakan. 6. Peralatan kebersihan meliputi : sapu, lap, ember, sprayer desinfektan.

Pakan yang diberikan mulai periode starter sampai finisher yaitu BR 1 "Patriot Feed" dengan kandungan protein kasar 20\%, serat kasar maksimal 5\%, lemak kasar maksimal 6\%, kalsium 0,9-1,1\%, dan phosphor $0,7-0,9 \%$. Probiotik yang digunakan dalam penelitian dibuat dengan memanfaatkan bakteri rumen dan usus ayam sebagai mikro organisme lokal (MOL). Aplikasi Probiotik, probiotik MOL diberikan pada broiler melalui pakan mulai umur 1 hari sampai panen 35 hari. Cara pembuatan tercantum pada Gambar 1.

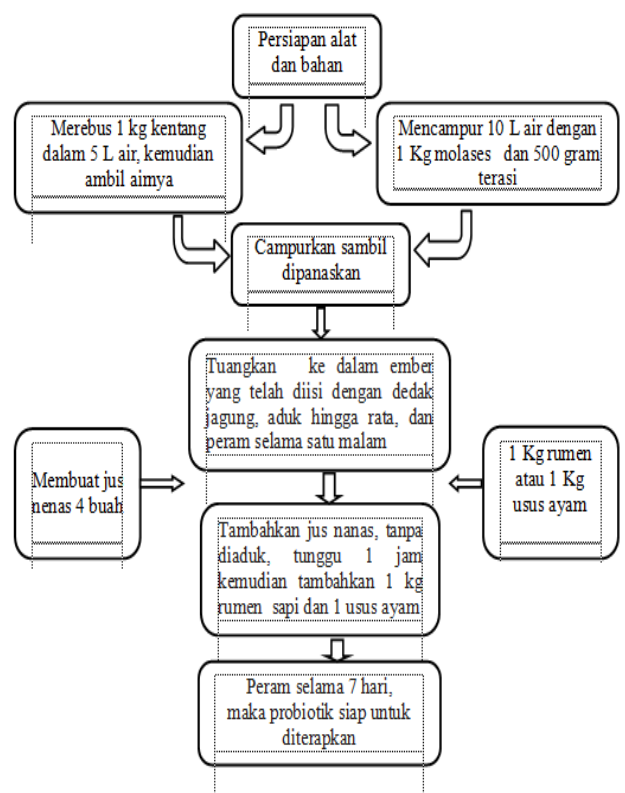

Figure 1. Skema Pembuatan Probiotik MOL 
Identifikasi bakteri probiotik yang terkandung dalam MOL dilakukan dengan cara uji morfologi (bentuk, warna koloni, dan pewarnaan gram) dan uji biokimia. Uji pewarnaan gram digunakan untuk mengetahui golongan bakteri. Uji biokimia dilakukan untuk mengidentifikasi dan mendeterminasi suatu biakan murni bakteri hasil isolasi melalui sifat-sifat fisiologisnya.Uji biokimia dilakukan dengan uji TSIA, MR-VP, sitrat, motilitas dan indol, katalase dan urease.

Penelitian ini menggunakan metode percobaan Rancangan Acak Lengkap. Perlakuan penelitian terdiri dari empat perlakuan dan lima kali ulangan. Setiap ulangan berisi sepuluh ekor broiler, sehingga jumlah broiler yang digunakan dalam penelitian ini sebanyak 200 ekor, adapun perlakuan yang diteliti adalah:

$\mathrm{P}_{0}=$ Perlakuan Kontrol (tanpa probiotik)

$\mathrm{P}_{1}=$ Pakan basal + probiotik dengan dosis $5 \mathrm{ml} /$ liter air

$\mathrm{P}_{2}=$ Pakan basal + probiotik dengan dosis $10 \mathrm{ml} / \mathrm{liter}$ air

$\mathrm{P}_{3}=$ Pakan basal + probiotik dengan dosis $15 \mathrm{ml} /$ liter air

Pengambilan data, data yang diambil pertama kali adalah konsentrasi mikro organisme probiotik yang meliputi Bifidobacterium, Bacillus, Streptococcus dan Lactseobacillus. Tahap kedua adalah mengamati parameter penelitian yang meliputi:

1. Persentase bobot karkas, dihitung dengan cara membagi bobot karkas dibagi dengan bobot potong

2. Lemak abdominal, dihitung dengan cara membagi bobot lemak abdominal dengan bobot potong dikalikan $100 \%$.

3. Lemak visceral, dihitung dengan cara membagi bobot lemak visceral dengan bobot potong dikalikan $100 \%$.

\section{HASIL DAN PEMBAHASAN}

Kandungan Mikroorganisme Probiotik di dalam MOL rumen sapi dan usus ayam tercantum pada Tabel 1 .

Tabel 1. Kandungan Mikro Organisme Probiotik PADA MOL

\begin{tabular}{lc}
\hline Jenis Mikro Organisme & $\begin{array}{c}\text { Konsentrasi } \\
(\mathrm{CFU} / \mathrm{ml})\end{array}$ \\
\hline Bacillus & $0,9 \times 10^{6}$ \\
Lactobacillus & $12,5 \times 10^{7}$ \\
Bifidobacterium & $3,5 \times 10^{7}$ \\
Streptococcus & $1,06 \times 10^{6}$ \\
\hline
\end{tabular}

Pada Tabel 1. Menunjukkan MOL yang dibuat dari rumen sapi dan usus ayam mengandung mikroorganisme probiotik yang dapat digunakan seperti Lactobacillus dan Bifidobacterium. Menurut Widiyaningsih (2011) probiotik mengandung bakteri spesies Lactobacillus dan Bifidobacterium. Spesies Lactobacillus dan Bifidobacterium terkandung dalam rumen sapi. Suardana (2007) menyatakan Lactococcus lactis spp dan Lactobacillus brevis merupakan bakteri antimikroba dalam rumen sapi. Selain di dalam rumen sapi bakteri probiotik terdapat juga di tembolok, usus halus dan ceca ayam terutama golongan Lactobacilli penghasil asam laktat dan asam asetat.

Pengaruh pemberian probiotik MOL terhadap persentase karkas, lemak abdominal dan lemak visceral broiler mengahasil data pada Tabel 2 .

TABEL 2. RATAAN PERSENTASE KARKAS, LEMAK ABDOMINAL DAN VISCERAL BROILER

\begin{tabular}{|c|c|c|c|}
\hline Perlakuan & $\begin{array}{c}\text { Bobot } \\
\text { Karkas } \\
(\%)\end{array}$ & $\begin{array}{c}\text { Lemak } \\
\text { Abdominal } \\
(\%)\end{array}$ & $\begin{array}{c}\text { Lemak } \\
\text { Viceral } \\
(\%)\end{array}$ \\
\hline P0 & $74,05^{\mathrm{ns}}$ & $1,54^{\mathrm{ns}}$ & $0,66^{\mathrm{ns}}$ \\
\hline P1 & $72,02^{\mathrm{ns}}$ & $1,85^{\mathrm{ns}}$ & $0,45^{\mathrm{ns}}$ \\
\hline P2 & $73,63^{\mathrm{ns}}$ & $1,62^{\mathrm{ns}}$ & $0,56^{\mathrm{ns}}$ \\
\hline P3 & $73,48^{\mathrm{ns}}$ & $1,60^{\mathrm{ns}}$ & $0,68^{\mathrm{ns}}$ \\
\hline
\end{tabular}

Keterangan: NS = Non Signifikan $(\mathrm{P}>0.05)$

\section{Pengaruh Probiotik terhadap Bobot Karkas}

Secara statistik penambahan probiotik MOL tidak berpengaruh nyata $(\mathrm{P}>0.05)$ tehadap persentase karkas dibandingkan dengan persentase karkas broiler tanpa diberi probiotik, demikian juga diantara persentase karkas broiler yang diberi probiotik pada level yang berbeda tidak menunjukkan persentase yang berbeda nyata, dengan demikian probiotik MOL dapat diberikan pada broiler karena presentase karkas yang diperoleh masih dalam kisaran normal yaitu 72,02-73,63\%. Menurut North and Bell (1992) menyatakan presentase karkas broiler normal bekisar antara $65-75 \%$ dari bobot hidup.

Penambahan probiotik dalam ransum tidak berpengaruh nyata terhadap persentase karkas broiler, hal ini disebabkan karena berat badan broiler pada akhir pemeliharaan menunjukkan tidak ada perbedaan nyata ( $\mathrm{p}>0,05)$ yaitu P1 1808.86 gram, P2 1858,40 gram, P2 1817,80 gram, dan P3 1769,02 gram. Penambahan probiotik, prebiotik dan kombinasi keduanya dalam ransum tidak 
Ujang Suryadi, Anang Febry Prasetyo, Erna K, Septy EE, Fuad A, Galih FF. Pemberian Probiotik Berbasis Mikroorganisme Lokal (MOL) Terhadap Kualitas Karkas Broiler

mempengaruhi pembentukan daging ayam broiler, sehingga belum dapat secara signifikan meningkatkan persentase bangkai broiler antara yang ditambahkan probiotik $68,04 \%$ dan yang tanpa probiotik 66,56\% (Daud, 2006).

\section{Pengaruh Probiotik terhadap Lemak Abdominal dan Visceral}

Penambahan probiotik MOL tidak berpengaruh nyata $(\mathrm{P}>0.05)$ tehadap persentase Lemak Abdominal dan visceral dibandingkan dengan persentase Lemak Abdominal dan visceral broiler tanpa diberi probiotik, demikian juga diantara pesentase Lemak Abdominal dan visceral broiler yang diberi probiotik pada level yang berbeda tidak menunjukkan persentase yang berbeda nyata. Harsil rataan persentase lemak abdominal yang diperoleh dalam penelitian ini masih dalam kisaran normal yaitu $1,52-1,85 \%$. Hal ini sesuai dengan pendapat Salam dkk. (2013), menyatakan bahwa presentase lemak abdominal broiler berkisar 0,73-3,78\%.

Tidak adanya perbedaan nyata pemberian probiotik MOL terhadap persentase lamak abdominal hal ini diduga bakteri probiotik yang terkandung di dalam MOL tidak dapat menurunkan aktivitas asetil-Co A karboksilase yang mengkatalisis pembatasan laju langkah dalam biosintesis asam lemak. Bakteri pada probiotik dapat menguraikan rantai panjang lemak. Bakteri asam laktat memfermentasikan karbohidrat yang menghasilkan asam lemak rantai pendek dalam saluran pencernaan (Ljung et al., 2005).

Menurut Santoso et al., (1995), probiotik secara efektif dapat menurunkan aktivitas asetil KoA karboksilase yaituenzim yang berperan dalam laju sintesis asam lemak. Abu-Elheiga et al. (1995)menyatakan bahwa turunnya aktivitas enzim Asetil KoA karboksilase merangsangsel-sel adiposa untuk mengoksidasi serta menghidrolisis lemak. Abu-Elheiga et al. (1997) juga menambahkan bahwa sel-sel adiposa akan mengoksidasi glukosa, halini berarti jaringan adiposa (termasuk lemak abdominal) menjadi lebih sedikit terlibat dalam sintesis dan dalam proses penyimpanan lemak.

Pemberian bakteri asam laktat dapat menurunkan lemak karkas, menurunkan trigliserida, karena BAL secara efektif menurunkan aktivitas enzim yang berperan dalam laju sintesis asam lemak (Santoso et al., 1995). Penurunan lemak pada daging disebabkan karena BAL menghasilkan enzim lipase yang dapat memecah lemak bermolekul besar menjadi substrat yang lebih kecil sehingga mudah dicerna (Sudha, 2005). Menurut Piliang et al. (1990) lingkungan asam menyebabkan aktivitas enzim lipase menjadi terbatas, sehingga pencernaan lemak berkurang dan pembentukkan lemak tubuhpun menjadi menurun.

Pemberian probiotik MOL tidak berpengaruh nyata terhadap presentase lemak abdominal broiler, hal ini sejalan dengan penelitian Daud (2006), bahwa pemberian probiotik (Bacillus $s p$ ) terhadap presentase lemak abdominal tidak memberikan pengaruh nyata.Selanjutnya Ikasari (2017) melaporkan bahwa pemberian probiotik (Enterococcus faecalis) tidak memberikan pengaruh nyata terhadap presentase lemak abdominal.

\section{KESIMPULAN}

Penambahan probiotik MOL pada pakan BR 1 tidak berpengaruh nyata $(\mathrm{P}>0.05)$ tehadap persentase karkas, lemak abdominal dan visceral broiler dibandingkan dengan persentase karkas, lemak abdominal dan visceral broiler tanpa diberi probiotik, demikian juga diantara pesentase karkas, lemak abdominal dan visceral broiler yang diberi probiotik pada level yang berbeda tidak menunjukkan persentase yang berbeda nyata $(\mathrm{P}>0.05)$, dengan demikian MOL dapat diberikan pada broiler karena presentase karkas yang diperoleh masih dalam kisaran normal yaitu 72,02-73,63\%, persentase lemak abdominal antara $1,54 \%-1,85 \%$, dan persentase lemak visceral $0,45 \%-0,68 \%$.

\section{UCAPAN TERIMAKASIH}

Peneliti mengucapkan terimakasih kepada P3M Politeknik Negeri Jember yang telah menyediakan dana penelitian yang bersumber dari PNBP sehingga penelitian ini dapat dilakukan sampai selesai.

\section{DAFTAR PUSTAKA}

[1] Abrar, A. dan Raudhati, E. 2006. Produktifitas dan aktifitas mikroba saluran pencernaan ayam broiler yang diberi probiotik. Penelitian DIK-S. fakultas Pertanian Universitas Sriwijaya.

[2] Abu-Elheiga, L., Jayakumar, A., Baldini, A., Chirala, S.S. \& Wakil, S.J. 1995.Human acetyl-CoA carboxylase: Molecular cloning, characterization,chromosomal mapping, and 
evidence for two isoforms.Proc. Natl. Acad. Sci. $92: 4011-4015$.

[3] Daud Muhammad. 2006. Persentase dan Kualitas Karkas Ayam Pedaging yang Diberi Probiotik dan Prebiotik dalam Ransum. JIT. Vol. 6. No. 3. h al 126-131.

[4] Ikasari A. T. 2017. Pengaruh Pemberian Probiotik Terhadap Presentase Karkas Dan Lemak Karkas Pada Broiler. Skripsi. Universitas Islam Negeri Alauddin Makassar. Makassar.

[5] Ljungh, A. and Wadstrom T. 2005. Lactic acid bacteria as probiotic. Curr.IssueIntestinal Microbiol. 7 : 73 90.

[6] North, M. D., and D. D. Bell. 1992. Commercial Chicken Production Manual. Second Edition. The Avi Publishing Co. Inc. Wesport, Conecticut.

[7] Piliang, W.G. 1990. Strategi Penyediaan Pakan Ternak Berkelanjutan Melalui Pemanfaatan Energi Alternatif. Orasi Ilmiah Guru Besar Tetap Ilmu Nutrisi. Fakultas Peternakan Institut Pertanian Bogor. Bogor.

[8] Riady, Erliana. 2018. Pakan Ternak AGP Dilarang, Ayam di Blitar Diserang Penyakit. https://news.detik.com.

[9] Salam, S., Fatahilah, A., Sunarti, D. dan Isroli. 2013. Bobot Karkas dan Lemak Abdominal Broiler yang Diberi Tepung Jintan Hitam (Nigella Sativa) dalam Ransum Selama Musim Panas. Jurnal Sains Peternakan. Vol 11 (2): 84-89.

[10] Santoso, U.S. Ohtani, K., Tanaka dan Sakaida. 1999. Dried Bacillus subtillis Culture reduced ammonia gass release in poultry house. Asian Australian Journal of Animal Sciences (AJAS) Vol. 12. No. 5. 677-842.

[11] Santoso U., Tanaka K., Ohtani S., 1995. Effect of dried Bacillus subtilis culture on growth, body composition and hepatic lipogenic enzyme activity in female broiler chicks, Br. J. Nutr. 74. 523-529.

[12] Sudha, M.R., C. Prashant, D. Kalpana, B. Sekhar, dan J. Kaiser. 2009. Probiotics as Complementary Therapy for Hypercholesterolemi. Biology and Medicine. Vol. 1 (4): Rev 4

[13] Yirga H 2015 The Use of Probiotics in Animal Nutrition. J. Prob. Health 3132 